\title{
Engineering Characteristics of Natural Wide Grading Gravelly Soil in Construction of Extra-High Earth-Rockfill Dam
}

\author{
Zhan Zhenggang $^{1}$, Cheng Ruilin ${ }^{1,2^{*}}$, Qiu Huanfeng ${ }^{1,2}$, Zhang Sheng ${ }^{1}$ \\ ${ }^{1}$ Guiyang Engineering Cooperation Limited of Power China, Guiyang, China \\ ${ }^{2}$ School of Water Resources and Hydropower Engineering, Wuhan, China \\ *Corresponding Author.
}

\begin{abstract}
Wide grading gravelly soil is an advantageous anti-seepage material in construction of high earth-rock dam. From the experience of earth-rockfill dam construction at home and abroad, it is more and more common to use wide grading gravelly soils such as moraine soil, weathered rock and gravel soil as anti-seepage material in construction of high earth-rockfill dams. Regarding the engineering characteristics of natural wide grading of soil material for 300m core-wall earth-rockfill dams in this paper, a series of physical and numerical tests were carried out to study its permeability and mechanical properties. By comparing the characteristics of impermeable soil materials of the projects already built and to be built at home and abroad, the preliminary indicators of impermeable soil materials are as follows: 1) Combined with the existing engineering experience and test results, the content of particles with particle size greater than $5 \mathrm{~mm}$ should be neither over $50 \%$ nor lower than $30 \%$. The content of particles with particle size less than $0.075 \mathrm{~mm}$ should not be less than 15\%; the content of clayey particles with particle size less than $0.005 \mathrm{~mm}$ should not be less than 6\%. 2) It is appropriate to control the permeability coefficient of impermeable soil material at less than $1 \times 10^{-5} \mathrm{~cm} / \mathrm{s}$.
\end{abstract}

Keywords: Natural wide grading gravelly soil, permeability characteristics, mechanical property, extra-high earth-rockfill dam

\section{Introduction}

From the experience of earth-rockfill dam construction at home and abroad, it is more and more common to use wide grading gravelly soils such as moraine soil, weathered rock and gravel soil as anti-seepage material in construction of high earth-rockfill dams. Using wide grading soil as seepage prevention material of high earth-rockfill dam has great advantages [1-2]. After compaction, this material can obtain a higher density, thus providing the strength of the impermeable body, reducing compressibility, making the deformation modulus of the impermeable body and the dam shell material more coordinated, effectively reducing the arch effect of the dam shell on the core wall, improving the stress and strain of the core wall, reducing the probability of the core wall crack, preventing the production of hydraulic splitting. When the impermeable body cracks, the cracks need to bypass the gravel to further extend. Therefore, the existence of coarse gravel can limit the development of fractures, increase the fluctuation difference of fractures, and reduce the hydraulic slope of seepage along fractures. At the same time, since the coarse particles are not easy to be eroded, it has a positive effect on limiting the seepage erosion along the fracture, and the self-healing effect of the fracture under the protection of reverse filtration is also better. Gravel soil is convenient for construction, and heavy construction machinery can be used for transportation and rolling. It is insensitive to water content, which is more beneficial for the construction in rainy areas than clay materials. Therefore, gravel-soil is used as impermeable material for many $200 \mathrm{~m}$ high earth-rockfill dams at home and abroad [3], and statistical results are shown in Table 1.

Table 1 indexes of typical engineering impermeable soil material

\begin{tabular}{|c|c|c|}
\hline Name of dam & Height & Indexes of impermeable soil material \\
\hline Oroville Dam & $230 \mathrm{~m}$ & The mixture of clay, silt, gravel and pebble is used, the maximum particle size is \\
\hline
\end{tabular}

ISSN: 0010-8189

(C) CONVERTER 2020

www.converter-magazine.info 


\begin{tabular}{|c|c|c|}
\hline & & $\begin{array}{l}76 \mathrm{~mm} \text {, and the content of particles with average particle size larger than } 5 \mathrm{~mm} \text { is } \\
45 \% .\end{array}$ \\
\hline Tehri Dam & $260 \mathrm{~m}$ & $\begin{array}{l}\text { The mixture of moderate plastic clay from the surface layer and sand gravel from the } \\
\text { lower layer is adopted. The content of fine material }(\leqslant 0.075 \mathrm{~mm}) \text { is not less than } \\
2 \% \text {, the content of clay particles }(\leqslant 0.002 \mathrm{~mm}) \text { is not less than } 7 \% \text {, the content of } \\
\text { particles with size larger than } 5 \mathrm{~mm} \text { is } 20 \sim 40 \% \text {, and the maximum particle size is } \\
200 \mathrm{~mm} \text {. Among them, sand gravel account for } 20 \% \sim 40 \% \text {, with particle size of } \\
75 \sim 150 \mathrm{~mm} \text {. }\end{array}$ \\
\hline Nurek Dam & $300 \mathrm{~m}$ & $\begin{array}{l}\text { A mixture of loam, sandy loam and gravel less than } 200 \mathrm{~mm} \text { is used. The content of } \\
\text { particle with size greater than } 5 \mathrm{~mm} \text { is } 20 \% \sim 40 \% \text {, and the maximum particle size at } \\
\text { the edge of the core wall is required to be less than } 70 \mathrm{~mm} \text {. }\end{array}$ \\
\hline $\begin{array}{l}\text { Waterfall gully } \\
\text { dam [4 5] }\end{array}$ & $186 \mathrm{~m}$ & $\begin{array}{l}\text { The wide grading gravel soil from the Heima soil yard with coarse particles greater } \\
\text { than } 80 \mathrm{~mm} \text { being removed is adopted. The content of particle with size less than } \\
5 \mathrm{~mm} \text { is } 40.24 \% \sim 49.76 \% \text {, the content of particle with size less than } 0.1 \mathrm{~mm} \text { is } \\
18.04 \% \sim 22.62 \% \text {, and the clay content is } 5.46 \% \sim 5.75 \% \text {. }\end{array}$ \\
\hline $\begin{array}{c}\text { Nuozhadu dam } \\
{[6]}\end{array}$ & $261.5 \mathrm{~m}$ & $\begin{array}{l}\text { The farm land soil mixed with } 35 \% \text { artificial gravel is adopted, with the maximum } \\
\text { particle size of } 120 \mathrm{~mm} \text {. The content of particles larger than } 5 \mathrm{~mm} \text { is } 30 \%-40 \% \text {, the } \\
\text { content of particles smaller than } 0.075 \mathrm{~mm} \text { is not less than } 15 \% \text {, and the content of } \\
\text { clay particles is not less than } 8 \% \text {. }\end{array}$ \\
\hline $\begin{array}{l}\text { Lianghekou } \\
\text { dam [7] }\end{array}$ & $295 \mathrm{~m}$ & $\begin{array}{l}\text { The soil from upstream Yiza, Yazhong, Apple orchard, Pugarong, Zhili Cun, Guali } \\
\text { yard and downstream Xidi yard mixed with } 40 \% \text { artificial gravel is adopted. The } \\
\text { content of particles with particle size greater than } 5 \mathrm{~mm} \text { shall not exceed } 50 \% \text {, and } \\
\text { the maximum particle size shall not be greater than } 150 \mathrm{~mm} \text {, so as not to affect the } \\
\text { compaction; The content of particle less than } 0.075 \mathrm{~mm} \text { is not less than } 15 \% \text {, and the } \\
\text { concentrated overhead of coarse material shall not occur during filling; The content } \\
\text { of clay less than } 0.005 \mathrm{~mm} \text { is not less than } 8 \% \text {. }\end{array}$ \\
\hline $\begin{array}{c}\text { Shuangjiangkou } \\
\text { dam [8] }\end{array}$ & $314 \mathrm{~m}$ & $\begin{array}{l}\text { The raw material mixed with } 50 \% \text { artificial gravel is adopted. The content of particle } \\
\text { greater than } 5 \mathrm{~mm} \text { is } 30 \sim 40 \% \text {, the maximum particle size is not greater than } 150 \mathrm{~mm} \text {, } \\
\text { so as not to affect the compaction. The content of particle less than } 0.075 \mathrm{~mm} \text { is not } \\
\text { less than } 15 \% \text {, and the concentrated overhead of coarse materials shall not occur } \\
\text { during filling. The content of clay less than } 0.005 \mathrm{~mm} \text { shall not less than } 8 \% \text {. }\end{array}$ \\
\hline
\end{tabular}

The properties of soil materials are greatly affected by the distribution of gradation. The better the particle composition distribution is, the easier it is to obtain a higher density after compaction, and the better its water impermeability and mechanical properties such as shear strength are [9]. Generally speaking, the more coarse particles in the soil, the more conducive to obtain higher density and shear strength and other mechanical properties and avoid excess pore water pressure, but the more detrimental to the anti-seepage performance. On the contrary, the more fine particles in the soil, the better the anti-seepage performance of soil, but the more unfavorable to obtain better density, shear strength and other mechanical properties and realize the dissipation of pore water pressure. In order to obtain better impervious performance and mechanical properties of soil materials, DL/T 5388-2007 regulations require that the maximum particle size of impervious soil materials for high dams should be neither greater than $150 \mathrm{~mm}$ nor more than $2 / 3$ of the thickness of the compacting soil layer, and the content of particles greater than $5 \mathrm{~mm}$ shall be controlled between $20 \%$ and $50 \%$. Therefore, combined with the characteristics of soil materials, artificial gravel is doped to better control the contents of $\mathrm{P}_{5}$ and other particles for the domestic projects of Shuangfugou, Lianghekou, Shuangjiangkou, Changheba and Nuozhadu.

For a 300m high core-wall earth-rockfill dam, the content range of $\mathrm{P}_{5}$ is larger and the grading is wider after the particles larger than $60 \mathrm{~mm}$ are removed. In order to understand the engineering characteristics of the soil, a series of physical tests and numerical test analysis were carried out to study the permeability characteristics, mechanical characteristics and engineering characteristics of the natural wide grading gravel soil [10].

\section{Study of permeability characteristics}

2.1 Permeability of soil materials

ISSN: 0010-8189

(C) CONVERTER 2020

www.converter-magazine.info 
2.1.1 Influence of $\mathrm{P}_{5}$ content

The influence of $\mathrm{P}_{5}$ content on soil permeability characteristics is shown in Fig. 1 and Fig. 2. The test results show that the content of $\mathrm{P}_{5}$ directly affected the permeability coefficient and slope of impermeable soil material. 1) As the content of $\mathrm{P}_{5}$ increased, the permeability coefficient increased. When the content of $\mathrm{P}_{5}$ increased to $50 \% \sim 55 \%$, the permeability coefficient of some soil samples began to exceed $1 \times 10^{5} \mathrm{~cm} / \mathrm{s}$. When $\mathrm{P}_{5}$ content $<50 \%$, the permeability coefficients were all less than $\left.1 \times 10^{5} \mathrm{~cm} / \mathrm{s} ; 2\right)$ With the increase of $\mathrm{P}_{5}$ content, the failure slope decreased, and when $\mathrm{P}_{5}$ content $>50 \%$, the failure declined more obviously, but a large failure slope was still maintained.

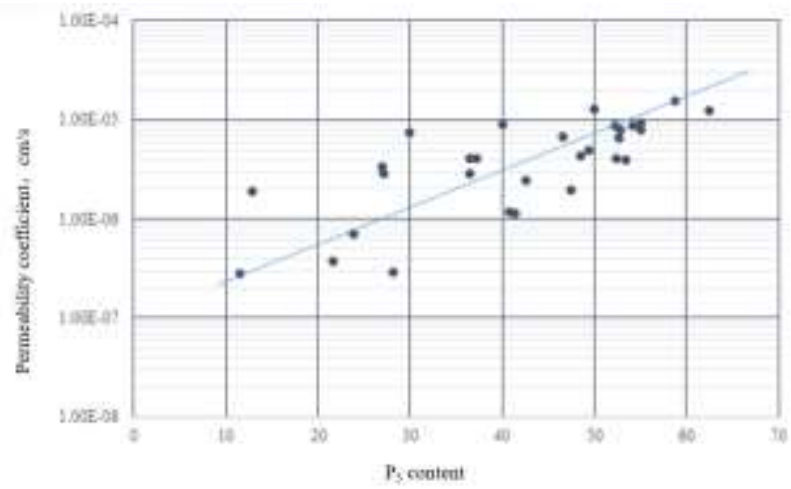

Fig. 1 Relationship curve between $P_{5}$ content and permeability coefficient

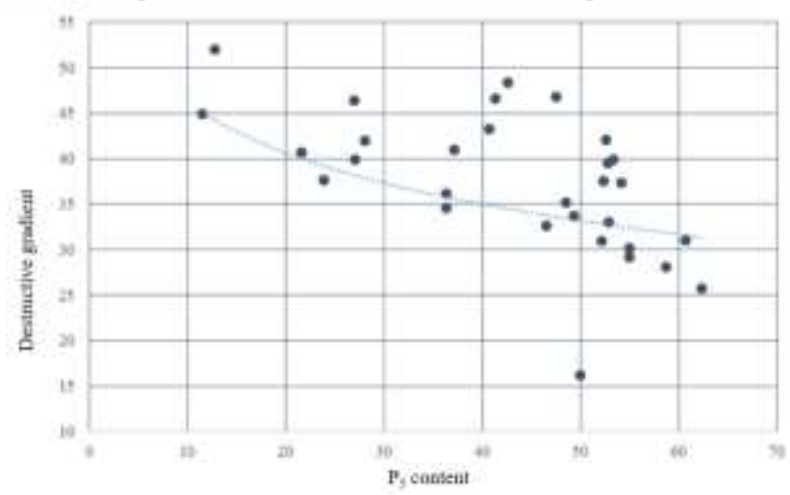

Fig. 2 Relationship curve between $P_{5}$ content and seepage slope

2.2.2 The influence of the content of fine grains $(<0.075 \mathrm{~mm},<0.005 \mathrm{~mm})$

Fig. 3 and Fig. 4 show the curve of soil permeability characteristics with fine grain content. The experimental results show that as the content of fine grain $(<0.075 \mathrm{~mm},<0.005 \mathrm{~mm})$ increased, the permeability coefficient decreased, however when the fine grain content reached a certain range, the permeability coefficient gradually became stable. When the content of fine grain $(<0.075 \mathrm{~mm})$ was less than $15 \%$ and the clay content was $4 \%$, the permeability coefficient was greater than $1 \times 10^{-5} \mathrm{~cm} / \mathrm{s}$.

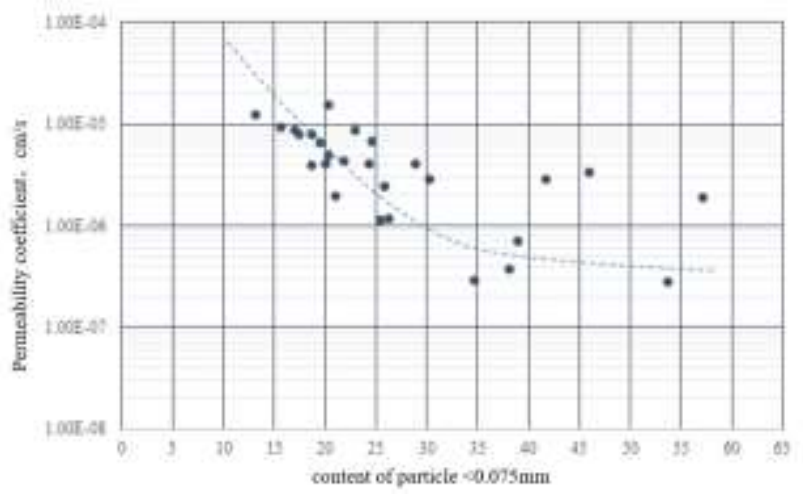

ISSN: 0010-8189

(C) CONVERTER 2020 
Fig. 3 Relation curve between content of particle $<0.075 \mathrm{~mm}$ and permeability coefficient

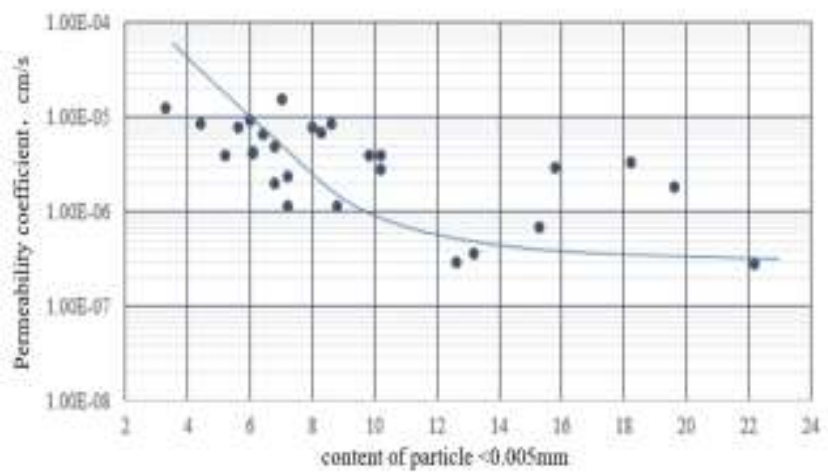

Fig. 4 Relation curve between content of particle $<0.005 \mathrm{~mm}$ and permeability coefficient

\subsection{Sensitivity analysis of permeability coefficient}

The sensitivity analysis of permeability coefficient of impermeable soil as core wall material was carried out, and calculation results are shown in Table 2 . The results show that when the permeability coefficient of core wall material was less than $1 \times 10^{-5} \mathrm{~cm} / \mathrm{s}$, with the decrease of the permeability coefficient, the seepage discharge per unit width and, maximum seepage slope of core wall showed little change.

Table 2 Sensitivity analysis of permeability coefficient of impermeable soil material

\begin{tabular}{|c|c|c|c|}
\hline Scheme & $\begin{array}{c}\text { Core wall permeability } \\
\text { coefficient }(\mathrm{cm} / \mathrm{s})\end{array}$ & $\begin{array}{c}\text { Seepage discharge per unit } \\
\text { width }\left(\mathrm{m}^{3} / \mathrm{d}\right)\end{array}$ & $\begin{array}{c}\text { Maximum seepage slope } \\
\text { of core wall }\end{array}$ \\
\hline 1 & $5.00 \times 10-5$ & 22.3 & 2.9 \\
\hline 2 & $1.00 \times 10-5$ & 10.5 & 3.0 \\
\hline 3 & $5.00 \times 10-6$ & 8.9 & 3.0 \\
\hline 4 & $1.00 \times 10-6$ & 7.6 & 3.1 \\
\hline
\end{tabular}

2.3 Influence of random defects of core wall on seepage field of dam body

It is assumed that the local random defects or uneven distribution will occur in the anti-seepage body (mainly the core wall) under the influence of dam material and construction factor (especially rolling process), which will decrease the local anti-seepage performance. In the three-dimensional finite element model, defect elements are randomly selected manually according to the element volume ratio, and the permeability coefficient of defect elements is amplified to a certain extent.

Table 3 Statistics of random defect units in construction of core wall

\begin{tabular}{|c|c|c|c|c|c|c|}
\hline \multicolumn{3}{|c|}{ Condition } & \multicolumn{4}{c|}{ Parameter } \\
\hline \multirow{2}{*}{ Part } & Name & No. & $\begin{array}{c}\text { Number of } \\
\text { units }\end{array}$ & $\begin{array}{c}\text { Volume } \\
(\mathrm{m} 3)\end{array}$ & $\begin{array}{c}\text { Volume percent } \\
(\%)\end{array}$ & $\begin{array}{c}\text { Permeability } \\
\text { coefficient }(\mathrm{cm} / \mathrm{s})\end{array}$ \\
\hline \multirow{4}{*}{$\begin{array}{c}\text { Complete core } \\
\text { wall }\end{array}$} & - & 15478 & $5.40 \mathrm{E}+06$ & 100 & $7.00 \mathrm{E}-06$ \\
\cline { 2 - 7 } wall & Defect 1 & QS1 & 589 & $2.71 \mathrm{E}+05$ & 5.02 & $7.00 \mathrm{E}-05$ \\
\cline { 2 - 7 } & Defect 2 & QS2 & 687 & $2.72 \mathrm{E}+05$ & 5.04 & $7.00 \mathrm{E}-05$ \\
\cline { 2 - 7 } & Defect 1+2 & QS3 & 1276 & $5.43 \mathrm{E}+05$ & 10.06 & $7.00 \mathrm{E}-05$ \\
\cline { 2 - 7 } & $\begin{array}{c}\text { Heterogeneous } \\
\text { random field }\end{array}$ & QS4 & 15478 & $5.40 \mathrm{E}+06$ & 100 & $\begin{array}{c}7 \mathrm{E}-6 \\
\text { in normal } \\
\text { distribution }\end{array}$ \\
\hline
\end{tabular}

Among them, three conditions were selected for random defects of the core wall: both defect 1 and defect 2 are $5 \%$

ISSN: 0010-8189

(C) CONVERTER 2020

www.converter-magazine.info 
defect conditions, and defect units in both conditions are not repeated. The distribution of defect units in the core wall is shown in Fig. 5 . Defect 3 is $10 \%$ defect condition, and the number of defect units is the sum of that under condition 1 and 2 . The detailed statistics of defect units of core wall are shown in Table 3.
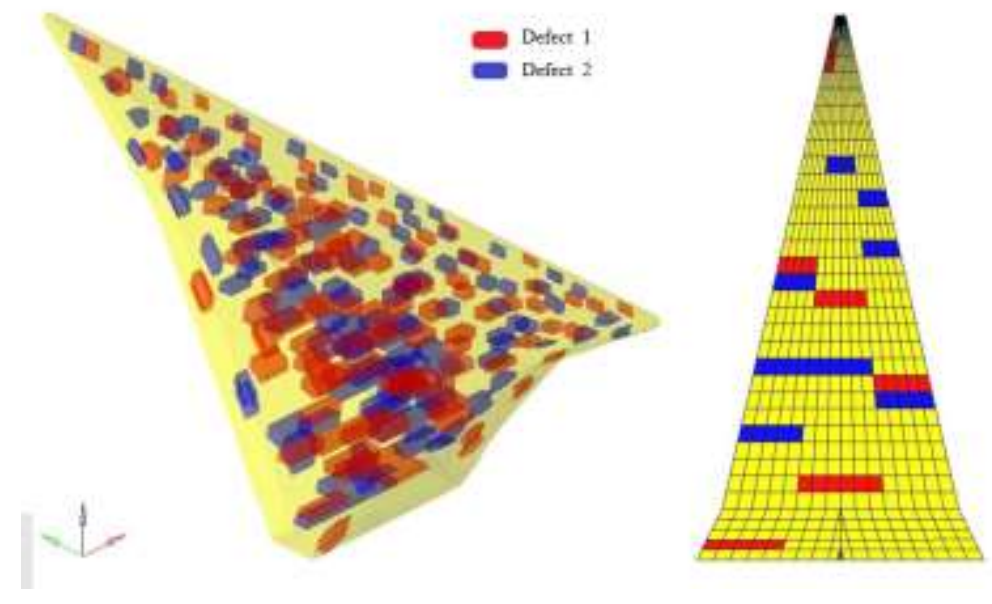

Fig. 5 Distribution diagram of defect units of core wall

In the finite element model, the random field value is used to assign the initial porosity ratio to the element nodes, and the linear relationship between the porosity ratio and the permeability coefficient is established to simulate the spatial variation of the permeability coefficient of the core wall material. When the pore ratio was 0 , the corresponding permeability coefficient was $7 \mathrm{E}-6 \mathrm{~cm} / \mathrm{s}$; when the pore ratio was 1 , the corresponding permeability coefficient was $1.4 \mathrm{E}-4 \mathrm{~cm} / \mathrm{s}$. The initial pore ratio distribution of the core wall in the three-dimensional finite element model is shown in Fig. 6. Due to the relatively large unit size and uneven spatial distribution, the local details are missing, which makes the pore ratio distribution of 3D model different from that of 2D model, but it can still reflect the characteristics of heterogeneity and randomness to a certain extent.

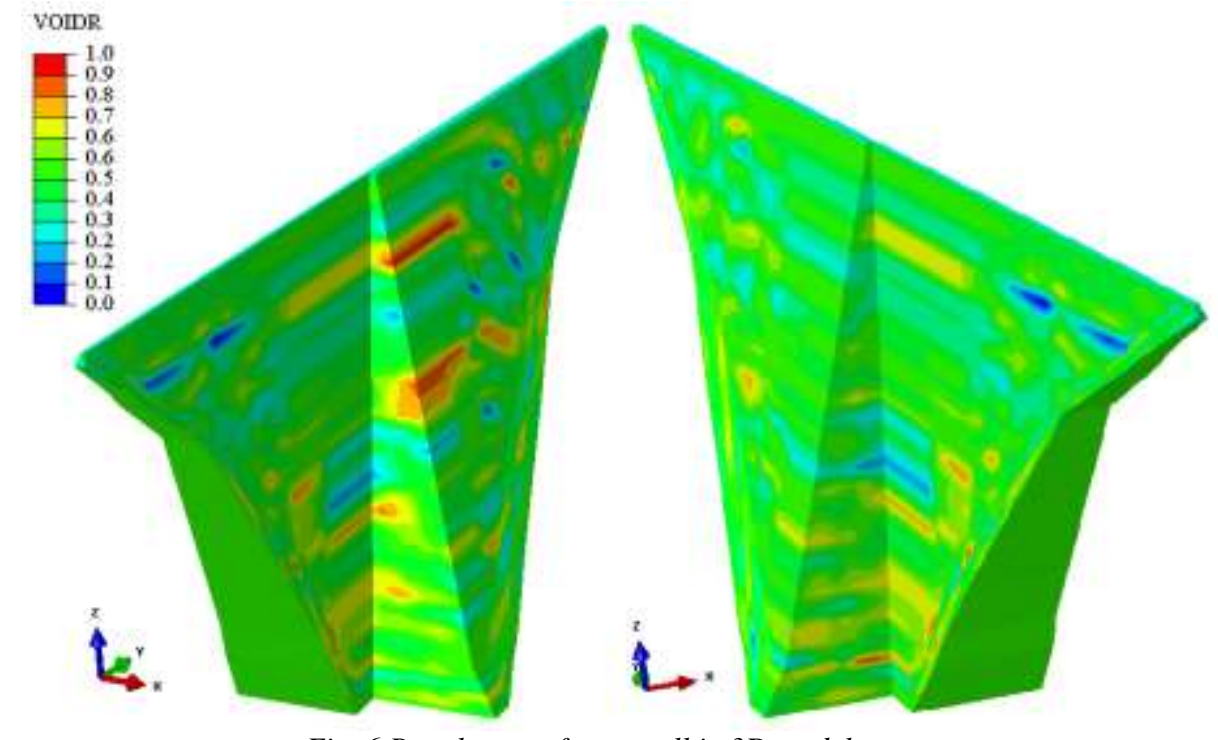

Fig. 6 Pore layout of core wall in 3D model

The maximum seepage slope of the core wall under each working condition is listed in Table 4, and the distribution of seepage slope of the core wall under the three working conditions (no defect, $10 \%$ defect and heterogeneous field) is shown in Figure 7 The simulation results show that the seepage slope of the defect area is small, but the permeability slope of the non-defect area is increased, with the occurrence of local mutation, and the local maximum seepage slope exceeds 8. As shown in Fig. 7(B2), the local area on the upstream surface of the core wall under $10 \%$ defect condition shows obvious mutation.

ISSN: 0010-8189

(C) CONVERTER 2020

www.converter-magazine.info 
Regarding the heterogeneity condition QS4, the change of the permeability coefficient in the core wall causes uneven distribution of seepage slope and local mutations, which however is not as serious as the defect condition, with the maximum seepage lope reaching 5.63. The results show that both the internal defects of the core wall and the uneven distribution of permeability coefficient have significant effects on the seepage slope, and the seepage slopes under the defect and heterogeneous conditions are both beyond the allowable seepage slope of the core wall, which have adverse effects on the overall permeability stability of the dam body.

Table 4 Influence of core wall defects on permeability

\begin{tabular}{|c|c|c|c|c|c|}
\hline $\begin{array}{c}\text { Condition } \\
\text { Permeability of core wall }\end{array}$ & $\begin{array}{c}\text { Design } \\
\text { condition } \\
\text { ZC }\end{array}$ & $\begin{array}{c}\text { Defect 5\% } \\
\text { QS1 }\end{array}$ & $\begin{array}{c}\text { Defect 5\% } \\
\text { QS2 }\end{array}$ & $\begin{array}{c}\text { Defect 10\% } \\
\text { QS3 }\end{array}$ & $\begin{array}{c}\text { Heterogeneous } \\
\text { field } \\
\text { QS4 }\end{array}$ \\
\hline $\begin{array}{c}\text { Permeability coefficient } \\
(\mathrm{cm} / \mathrm{s})\end{array}$ & $7.0 \mathrm{E}-6$ & $\begin{array}{c}7.0 \mathrm{E}-6 \\
7.0 \mathrm{E}-5(5 \%)\end{array}$ & $\begin{array}{c}7.0 \mathrm{E}-6 \\
7.0 \mathrm{E}-5(5 \%)\end{array}$ & $\begin{array}{c}7.0 \mathrm{E}-6 \\
7.0 \mathrm{E}-5(10 \%)\end{array}$ & $\begin{array}{c}7 \mathrm{E}-6 \sim \\
1.4 \mathrm{E}-4\end{array}$ \\
\hline $\begin{array}{c}\text { Water head difference } \\
\text { between upstream and } \\
\text { downstream (m) }\end{array}$ & 258.83 & 256.22 & 256.04 & 254.32 & 256.93 \\
\hline $\begin{array}{c}\text { Reduction percentage of } \\
\text { water head (\%) }\end{array}$ & 93.55 & 92.61 & 92.54 & 91.92 & 92.86 \\
\hline Maximum seepage slope & 3.647 & 8.458 & 8.505 & 8.505 & 5.630 \\
\hline
\end{tabular}

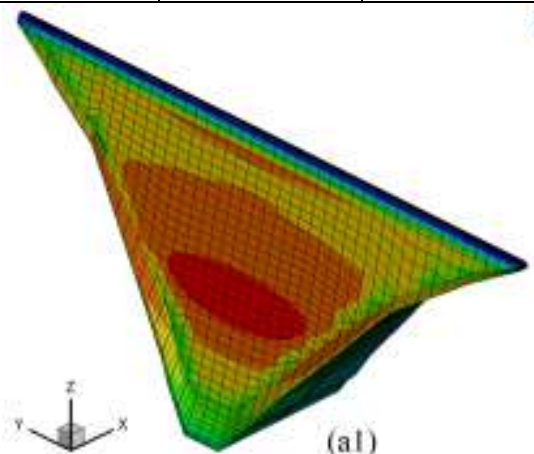

(al)

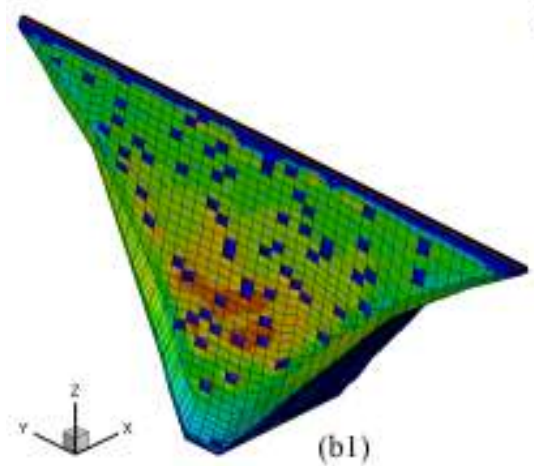

(b1)

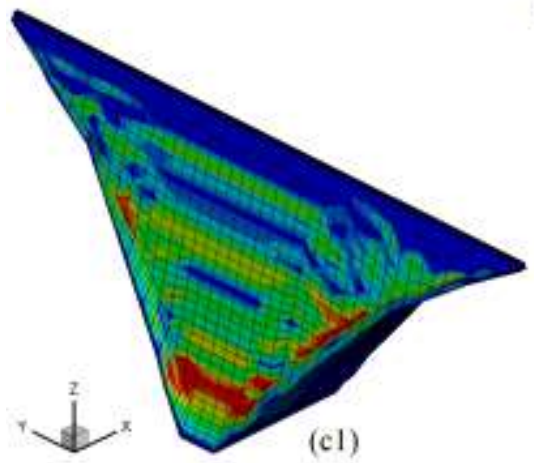

(c1)

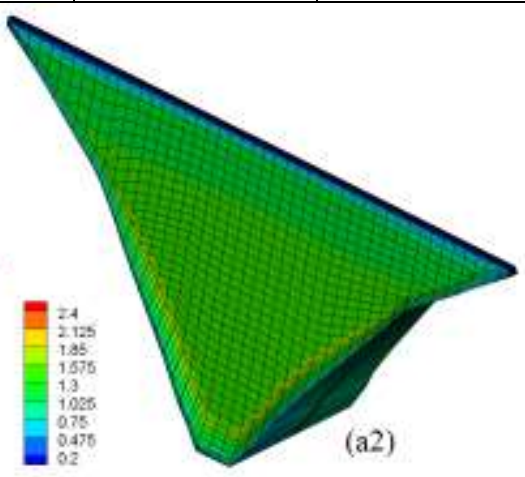

(a2)
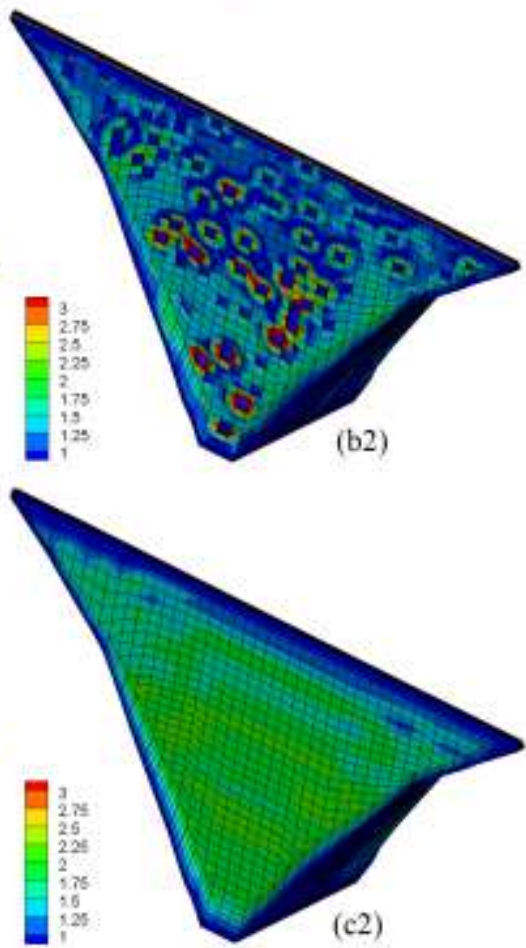

(c2)

ISSN: 0010-8189

(C) CONVERTER 2020 
Design condition (ZC); (b) 10\% defect condition (QS3); (c) Heterogeneous working condition (QS4)

(Left is the downstream side, right is the upstream side)

Fig. 7 Comparison of core wall seepage slope distribution under different working conditions

\section{Analysis of mechanical property}

\subsection{Experimental study on mechanical properties}

In order to understand the strength and deformation characteristics of soil, 67 groups of compression tests and 71 groups of triaxial (CD) tests were conducted. The statistical results are shown in Figure 5 - Figure 7. The results show that: 1) the compression modulus increased with the increase of $\mathrm{P}_{5}$ content. When the $\mathrm{P}_{5}$ content was $20 \% \sim 50 \%$, the compression modulus was about $16 \sim 30 \mathrm{MPa}$. 2) Internal friction angle increased with the increase of $\mathrm{P}_{5}$ content. When the $\mathrm{P}_{5}$ content was $20 \%-50 \%$, the internal friction angle was about $30.5 \sim 33.5$. 3) For the parameters of Duncan-Zhang E-B model, $\mathrm{K}$ increased with the increase of $\mathrm{P}_{5}$ content. When $\mathrm{P}_{5}$ content was $20 \% \sim 50 \%, \mathrm{~K}$ was about $310-550$. $\mathrm{N}$ decreased with the increase of $\mathrm{P}_{5}$ content. When $\mathrm{P}_{5}$ content was $20 \% \sim 50 \%, \mathrm{~N}$ was about $0.48-0.43$.

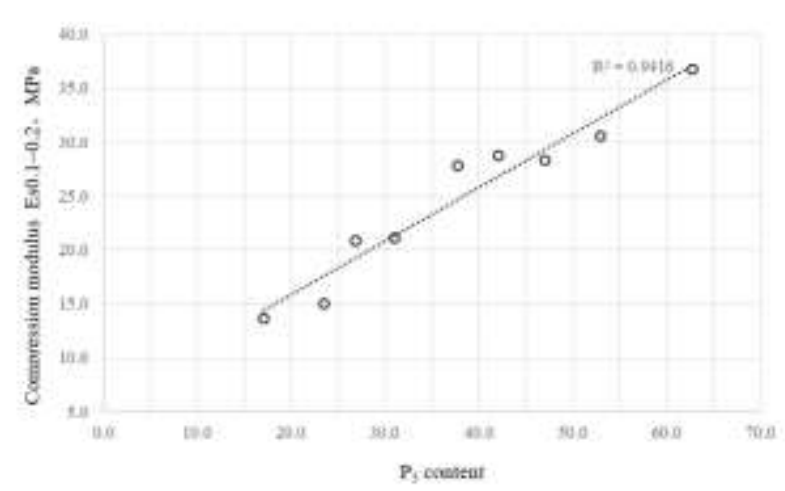

Fig. 5 Relationship between compression modulus and $P_{5}$ content

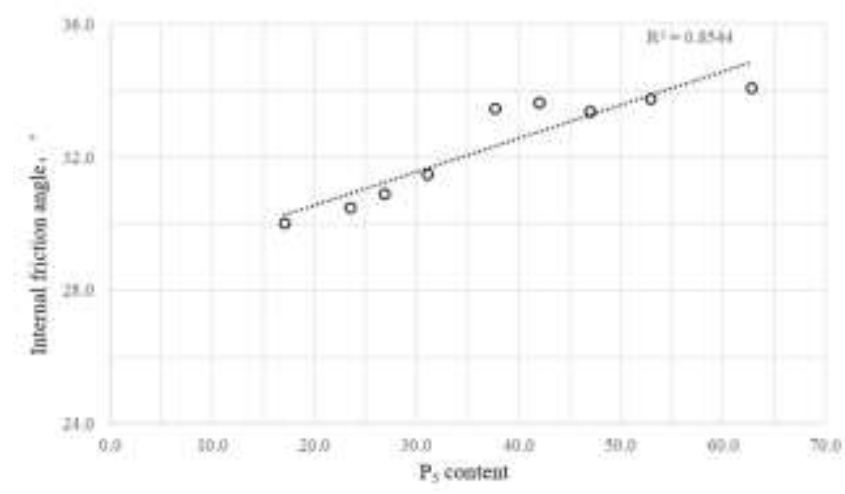

Fig. 6 Relationship between and P5 content

ISSN: 0010-8189 


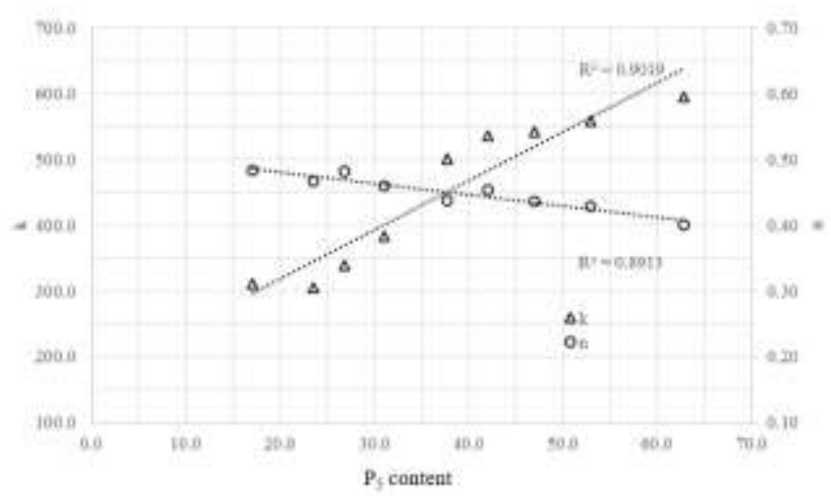

Fig. 7 Relationship between Duncan parameters $K$ and $n$ and P5 content P5

3.2 Influence of $\mathrm{P}_{5}$ content on deformation of dam body

As can be seen from Table 5, with the increase of $\mathrm{P}_{5}$ content, the compressive modulus, cohesion and internal friction angle of impermeable soil material, as well as $\mathrm{K}$ and $\mathrm{KB}$ in Duncan model parameters basically showed an increasing trend, while Duncan model parameters $\mathrm{n}$ and $\mathrm{m}$ basically showed a decreasing trend, and the parameter Rf showed little change.

Table 5 Statistics of P5 content, strength and deformation parameters of gravelly soil material of core wall (average)

\begin{tabular}{|c|c|c|c|c|c|c|c|c|c|}
\hline \multicolumn{2}{|c|}{$\mathrm{P}_{5}$ content } & \multirow{2}{*}{$\begin{array}{c}\begin{array}{c}\text { compressive } \\
\text { modulus }\end{array} \\
E_{S 0.1-0.2}\end{array}$} & \multirow{2}{*}{$\begin{array}{c}\text { cohesion } \\
\qquad c_{d}\end{array}$} & \multirow{2}{*}{$\begin{array}{c}\begin{array}{c}\text { internal } \\
\text { friction } \\
\text { angle }\end{array} \\
\varphi_{d}\end{array}$} & \multicolumn{5}{|c|}{ Main parameters of Duncan model } \\
\hline $\begin{array}{c}\text { Statistical } \\
\text { range }\end{array}$ & $\begin{array}{c}\text { average } \\
\text { value }\end{array}$ & & & & $\mathrm{K}$ & $\mathrm{n}$ & Rf & $\mathrm{kb}$ & $\mathrm{m}$ \\
\hline$\%$ & $\%$ & $\mathrm{MPa}$ & $\mathrm{kPa}$ & o & - & - & - & - & - \\
\hline$<20$ & 17.1 & 13.7 & 93.7 & 30.0 & 310.7 & 0.48 & 0.82 & 228.9 & 0.35 \\
\hline $20 \sim 25$ & 23.6 & 15.0 & 98.9 & 30.5 & 305.2 & 0.47 & 0.78 & 221.8 & 0.40 \\
\hline $25 \sim 30$ & 26.8 & 20.8 & 79.3 & 30.9 & 339.2 & 0.48 & 0.81 & 243.3 & 0.36 \\
\hline $30 \sim 35$ & 31.1 & 21.1 & 103.0 & 31.5 & 383.7 & 0.46 & 0.79 & 267.5 & 0.37 \\
\hline $35 \sim 40$ & 37.7 & 27.8 & 123.7 & 33.6 & 500.1 & 0.44 & 0.84 & 325.5 & 0.35 \\
\hline $40 \sim 45$ & 42.0 & 28.7 & 130.2 & 33.7 & 535.6 & 0.45 & 0.83 & 335.2 & 0.32 \\
\hline $45 \sim 50$ & 47.0 & 28.3 & 138.1 & 33.5 & 542.5 & 0.44 & 0.82 & 345.0 & 0.32 \\
\hline $50 \sim 55$ & 52.9 & 30.5 & 137.5 & 33.7 & 558.0 & 0.43 & 0.83 & 339.3 & 0.35 \\
\hline$>55$ & 62.8 & 36.7 & 139.5 & 34.1 & 594.5 & 0.40 & 0.79 & 349.1 & 0.32 \\
\hline
\end{tabular}

In order to further analyze the influence of $\mathrm{P}_{5}$ content on the deformation of the dam body, three-dimensional finite element static calculation was carried out under five schemes with average $\mathrm{P}_{5}$ content of $26.8 \%, 31.0 \%, 37.7 \%, 42.0 \%$ and $47.0 \%$ (Table 5). The calculation results of dam deformation extremum are shown in Table 6. It can be seen from Table 6 that the content of $\mathrm{P}_{5}$ material of the gravel core wall mainly affects the settlement of the dam body and the displacement along the river. The higher the content of $\mathrm{P}_{5}$, the stronger the resistance to deformation of the dam body, and the better the deformation coordination between the core wall and the dam shell. From the perspective of deformation control, the content of $\mathrm{P}_{5}$ in $300 \mathrm{~m}$ high dam should be controlled near $50 \%$.

ISSN: 0010-8189

(C) CONVERTER 2020

www.converter-magazine.info 
Table 6 Calculation results of dam deformation extremum under different $\mathrm{P}_{5}$ contents

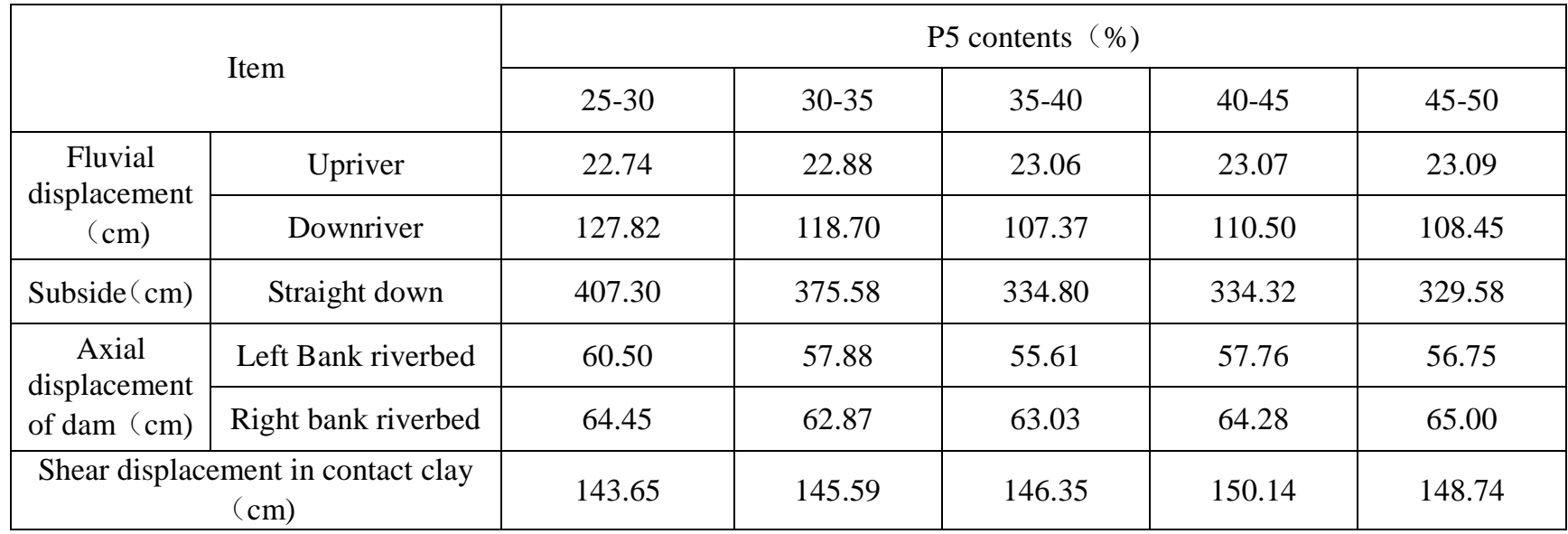

3.3 Influence of uneven $\mathrm{P}_{5}$ content on deformation of dam body

According to the characteristics of impermeable soil material, the sensitivity analysis of core wall material with $\mathrm{P}_{5}$ content between $25 \%$ and $30 \%$ was carried out. The unit with $15 \%$ area ratio of the core wall was randomly selected to assign ground parameters, and the stochastic finite element model was established, as shown in Fig. 8. The parameters of Duncan-Chang E-B model are shown in Table 5. Sensitivity analysis was carried out under two schemes (scheme I: all parameters with $\mathrm{P}_{5}$ content of $31.1 \%$; Scheme $2: 85 \%$ of the units adopted parameters with $\mathrm{P}_{5}$ content of $31.1 \%, 15 \%$ of the units adopted parameters with $\mathrm{P}_{5}$ content of $26.8 \%$ ) .

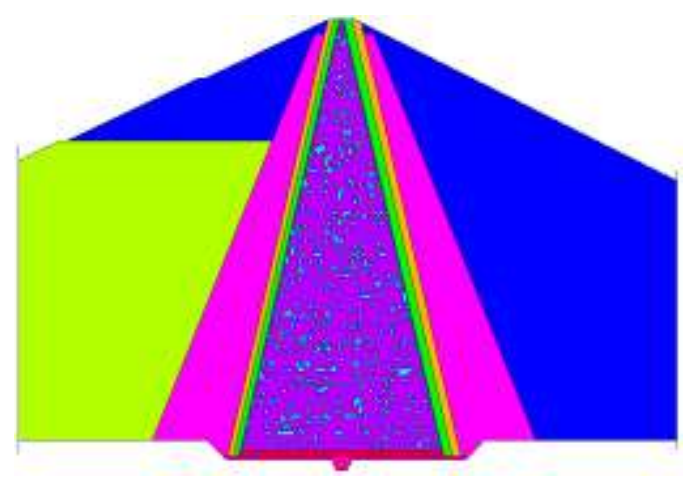

Fig. 8 Two-dimensional stochastic finite element mesh model

Table 7 Calculation parameters of core wall material by two-dimensional stochastic finite element method (Duncan-Chang model)

\begin{tabular}{|c|c|c|c|c|c|c|c|c|c|c|c|c|}
\hline \multirow{2}{*}{$\mathrm{P}_{5}$ content } & $c_{d}$ & $\varphi_{d}$ & $\varphi_{0}$ & $\Delta \varphi$ & $K$ & $n$ & $R_{f}$ & $K_{b}$ & $m$ & $D$ & $G$ & $F$ \\
\cline { 2 - 34 } & $\mathrm{kPa}$ & $\mathrm{o}$ & $\mathrm{o}$ & $\mathrm{o}$ & - & - & - & - & - & - & - & - \\
\hline $31.1 \%$ & 112.5 & 31.8 & 38.7 & 3.7 & 373.5 & 0.46 & 0.76 & 309.3 & 0.34 & 1.1 & 0.39 & 0.06 \\
\hline $26.8 \%$ & 93.8 & 29.7 & 35.1 & 3.5 & 323.0 & 0.42 & 0.76 & 259.8 & 0.40 & 1.4 & 0.44 & 0.05 \\
\hline
\end{tabular}

As can be seen from Table 7: 1) under the two schemes, the settlement of the core wall material, the distribution of the main compressive stress, and the displacement along the river were basically the same. 2) Since the soil with $25 \%$ $30 \% \mathrm{P}_{5}$ content accounted for $15 \%$ of the total project volume, which was a small proportion, the settlement of the core wall material, the main compressive stress and the displacement along river direction were the same under the two schemes. Under the scheme 1, the maximum settlement of the core wall was about $4.19 \mathrm{~m}$, the maximum river-direction

ISSN: 0010-8189

(C) CONVERTER 2020

www.converter-magazine.info 
displacement was about $1.30 \mathrm{~m}$, and the maximum principal compressive stress was about 5.3MPa. Under scheme 2 , the maximum settlement of the core wall was about $4.23 \mathrm{~m}$, the maximum river-direction displacement was about $1.31 \mathrm{~m}$, and the maximum principal compressive stress was about $5.3 \mathrm{MPa}$. It can be known that the dispersion of $\mathrm{P}_{5}$ content in impermeable soil material exists in a small range, which has a small effect on the stress and deformation of the dam body.

\section{Conclusions}

In this paper, a series of tests and numerical analysis were carried out to analyze the engineering characteristics of the natural wide grading of a 300m core wall earth-rockfill dam. The permeability and mechanical properties of core wall soil material were studied, and the properties of impermeable soil materials of the projects built and to be built at home and abroad were compared. The engineering impermeable soil material indexes are preliminarily drawn up as follows:

1) Combined with the existing engineering experience and test results, as the impermeable material of high core wall earth-rockfill dam, the gravel soil with particle size greater than $5 \mathrm{~mm}$ should be neither exceeding $50 \%$ nor less than $30 \%$. The content of particles less than $0.075 \mathrm{~mm}$ should be no less than $15 \%$; The content of clayey particles size less than $0.005 \mathrm{~mm}$ should be no less than $6 \%$.

2)According to the seepage monitoring results of existing projects and the permeability coefficient sensitivity analysis of impermeable soil material, it is appropriate to control the permeability coefficient of impermeable soil material to be less than $1 \times 10^{-5} \mathrm{~cm} / \mathrm{s}$ for high core wall earth-rockfill dam.

\section{Acknowledgements}

High-level Innovative Talents Project of Guizhou Province (2018) 5630; Guizhou Science and support (2019) 2869; Science and Technology Project of Huaneng Group Headquarters, HNKJ17-H18.

\section{References}

[1] Z. L. Zhang. "Research and engineering application of key technology for construction of 200m high earth-rockfill dam with core wall,” Beijing: China Water Power Press, 2011.

[2] J. H. Zhu, Y. Fan, K. H. Yang. "Impermeability and inverse filtration of wide grading gravel soil materials for dam construction," Chinese Journal of Geotechnical Engineering, no. 6, pp. 8-26, 1993.

[3] Z. L. Chen. "The world's superdams,” China Electric Power Press, 1998.

[4] "Report on preliminary design adjustment and optimization of Pubugou hydropower station, dadu river, sichuan province - engineering layout and construction," Chengdu Engineering Corporation Limited. vol. 3, 2003.

[5] D. X. Chen, G. G. Yuan, H. Lv, B. J. Zhang. "Study on impermeable soil material for pubugou hydropower station. Sichuan Water Power," no. 2, pp. 1-56, 1996.

[6] "Design report of c3 bid for nuozhadu hydropower station - hub layout and buildings," Chengdu Engineering Corporation Limited.

[7] "Feasibility study of lianghekou hydropower station on yalong river in sichuan and special report on the design of core wall earth-rockfill dam," Chengdu Survey and Design Institute of Hydrochina Corporation. vol. 4, 2008.

[8] "Feasibility study report on shuangjiangkou hydropower station, dadu river, sichuan province - engineering layout and construction (draft consultation)," Chengdu Engineering Corporation Limited. vol. 8, 2007.

[9] G. G. Yuang, B. J. Zhangi, D. X. Chen. "Seepage resistance of coarse grained soil," Journal of Underground Space, vol. 10, 1999.

[10] R. L. Cheng, H. F. Qiu, S. Zhang. "Study on engineering characteristics of natural wide grading gravel soil," Proceedings of the 2016 Annual Conference of Chinese National Commitee on Large Dams, 2016.

ISSN: 0010-8189

(C) CONVERTER 2020 